\title{
Introduction
}

\section{George Woodyard, Maestro: Seven Testimonies}

\section{Jorge Dubatti}

The Educational Component Unit of the XXVI International Hispanic Theatre Festival of Miami (July 8-9, 2011), organized by Teatro Avante in collaboration with the Latin American Theatre Review, University of Kansas, and Prometeo Theatre of the Florida Center for the Literary Arts at Miami Dade College, with the support of the John S. and James L. Knight Foundation, held a conference as a tribute to George Woodyard, called "Current Trends in Latino and Latin American Performing Arts," under the direction of Beatriz J. Rizk. One of the most relevant and moving moments of the event was the Roundtable "George Woodyard, Latin American Theatre Review, and the Development of U.S. Latino and Latin American Theatre Studies Today." The participants: Jorge Huerta (University of California, San Diego, CA), Adam Versényi (University of North Carolina at Chapel Hill, NC), Jacqueline Bixler (Virginia Tech, Blacksburg, VA), Stuart Day (University of Kansas, KS), Jean Graham-Jones (Graduate School and University Center CUNY, NY), Kirsten Nigro (University of Texas at El Paso, TX), and Beatriz J. Rizk (International Hispanic Theatre Festival of Miami, FL), were professionally involved with the great maestro and enjoyed his friendship.

We include here the seven testimonies given on that occasion. Upon reading them, the prologue written by Jorge Luis Borges to Pedro Henríquez Ureña's Obra crítica (1960) comes to mind. In this text, Borges defines what a "maestro" is with these lovely words:

Evidently, maestro is not the one who teaches isolated events or the one who dedicates himself to the mnemonic task of learning and repeating them, for in that case an encyclopedia would be a better maestro than a man. Maestro is the one who teaches by example the way to approach things, a generic style to confront the incessant and 


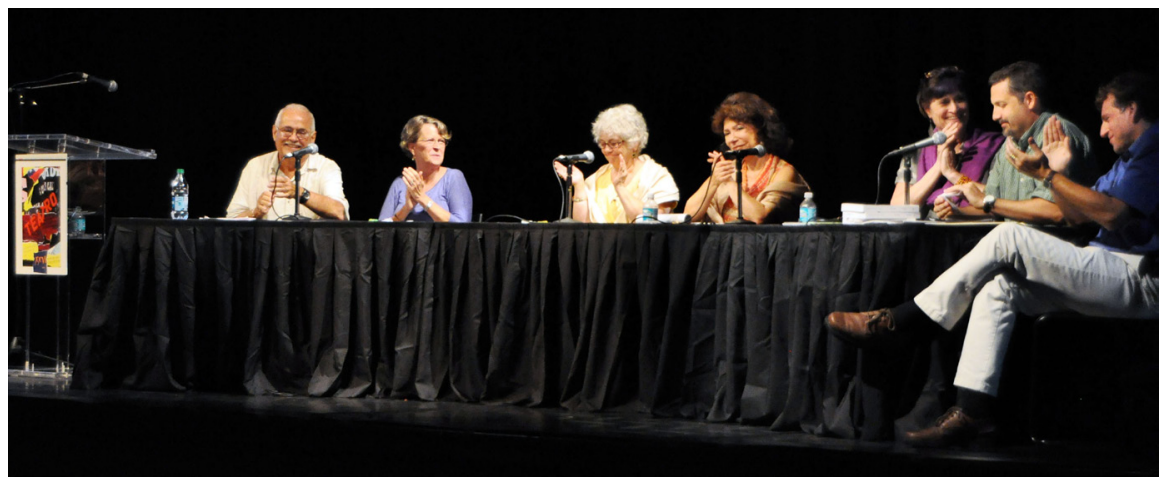

From left to right: Jorge Huerta, Jacqueline Bixler, Kirsten Nigro, Beatriz Rizk, Jean Graham-Jones, Stuart Day, and Adam Versényi reflect on the legacy of George Woodyard. Photo: Sara McCranie.

varied world. Teaching has many resources at its disposal; the direct word is only one. (vii)

Borges adds:

Ideas that are dead on paper were stimulating and alive for whoever listened and kept them, because behind them, and around them, there was a man. That man and his reality bathed them. An intonation, a gesture, a face, gave them a virtue which is lost today. There is room here to remember the historic and symbolic case of a Jewish man who went to the town of Mezeritz, not to listen to the preacher but to see how he tied his shoelaces. Clearly, everything was exemplary in that maestro, even everyday actions. Martin Buber, to whom we owe this peculiar anecdote, talked about maestros who not only exposed the Law but were the Law. (vii)

This is the spirit evoked in the seven testimonies about George Woodyard's image which follow this introduction.

These seven texts reveal different and complementary traits about Woodyard, one and multiple, always a maestro in the complete sense that Borges defined. Adam Versényi emphasizes George's way of behaving regarding knowledge, his generosity and modesty, through the remembrance of an initial letter that he responded to, the first communication in what became a long series of contacts and works. According to Versényi, Woodyard made real the emblematic phrase "someone who helps others do their best work." Jorge Huerta points out George's passion for theatre, his love for Latin America, and confirms that while he doesn't remember when they first met he feels as if he always knew him. Jacqueline Bixler chooses to talk about 
the bonds she established with George as a student and as an associate in the editing of the Latin American Theatre Review, and defines him as a "human compass" who directed her through Mexican and Argentinian theatre's pathways. Jean Graham-Jones evokes the text she asked Woodyard to write for Theatre Journal: "The Theatre Journal Auto/Archive," in which George set up the main framework for an intellectual autobiography in relation to theatre, and especially to Latin America. Kirsten Nigro remembers him as "an extraordinary human being" at the helm of an entire movement of researchersdisciples who followed in his footprints. Beatriz Rizk uncovers other facets of George: traveler, panelist, international conference-goer throughout the world. Stuart Day refers to George as the founder of an enormous library of specialized books and magazines, as well as the procreator of an "extended family" for whom he was "father, grandfather, and great-grandfather" for successive generations. The life and the example set by George Woodyard has also left a legacy in the University of Buenos Aires, firstly through the work of my professor Osvaldo Pellettieri, and then through direct contact with the American maestro; I am proud to say that I feel part of the "extended family" that Stuart Day talks about.

\section{Universidad de Buenos Aires}

\section{Works Cited}

Borges, Jorge Luis. “Prólogo.” Obra crítica. Pedro Henríquez Ureña. México: Fondo de Cultura Económica, 1960. vii-x. 
